\title{
The Paris agreement and key actors' domestic climate policy mixes: comparative patterns
}

\author{
Jon Birger Skjærseth ${ }^{1}$. Steinar Andresen ${ }^{1}$ - Guri Bang ${ }^{2}$. Gørild M. Heggelund ${ }^{1}$
}

Accepted: 25 January 2021 / Published online: 18 February 2021

(c) The Author(s), under exclusive licence to Springer Nature B.V. part of Springer Nature 2021

\begin{abstract}
This article examines two important conditions for achieving the Paris Agreement's (PA) ambitious goals. The first is the actions of the largest emitters-China, the European Union (EU) and the USA whose combined share of global emissions is near 50\%. The second condition is the bottom-up design of the PA itself. Drawing on the policy mix literature and comparison of the three major emitters examined in this special feature (see Bang, Heggelund and Skjærseth), we first conclude that the EU has the most ambitious climate targets and policy mixes needed for achieving net zero emissions. Second, the PA has contributed to more ambitious targets and policy mixes mainly in the EU but also in China. Ambitious EU actors have actively invoked the PA goals to further their interests and legalize the Agreement's dynamic five-year cycles. With Biden as president the USA will again be a party to the PA and is set to join the EU and China in upgrading ambitions. Looking towards the future, the USA and particularly China will have to, in one way or another, to follow the EU if net zero emissions are to be achieved. This may necessitate actual EU leadership by example.
\end{abstract}

Keywords The Paris agreement $\cdot$ Key actors $\cdot$ Domestic politics $\cdot$ Technology $\cdot$ Transition

$\begin{array}{ll}\text { Abbreviations } \\ \text { CCS } & \text { Carbon capture and storage } \\ \text { COP } & \text { Conference of the parties } \\ \text { ETS } & \text { Emissions trading scheme } \\ \text { EU } & \text { European union } \\ \text { FYP } & \text { Five-year plans }\end{array}$

Jon Birger Skjærseth jbskjaerseth@fni.no

Steinar Andresen sandresen@fni.no

Guri Bang

guri.bang@nupi.no

Gørild M. Heggelund

gheggelund@fni.no

1 The Fridtjof Nansen Institute (FNI), Fridtjof Nansens vei 17, P.O.Box 326, 1326 Lysaker, Norway

2 Norwegian Institute of International Affairs (NUPI) and CICERO, Oslo, Norway 


$\begin{array}{ll}\text { GHG } & \text { Greenhouse gas } \\ \text { NDC } & \text { Nationally determined contribution } \\ \text { PA } & \text { Paris agreement } \\ \text { USA } & \text { United States of America }\end{array}$

\section{Introduction}

The 2015 Paris Agreement (PA) aims to hold the global average temperature increase to 'well below $2{ }^{\circ} \mathrm{C}$ above pre-industrial levels and pursuing efforts to limit the temperature increase to $1.5{ }^{\circ} \mathrm{C}$ above pre-industrial levels' (Art. 2). This goal is linked to the requirement that all countries work together to bring greenhouse gas (GHG) emissions to net zero by the second half of the twenty-first century. Given the vagueness of the target as to timing (2050-2100), it is indeed very difficult-if not impossible-to evaluate or precisely measure the goal achievement of the PA. With this caveat in mind, this article aims to examine two crucial conditions for achieving the PA's ambitious targets.

The first condition is related to the actions of the largest emitters of GHGs. China, the European Union (EU) and the USA account for nearly half of the total global GHG emissions: 26\% (China), 8\% (EU), and 13\% (USA) (Ge and Friedrich 2020). The climate/energy policies of these three key actors will therefore to a large extent determine the fate of the PA. What is the status for these actors' climate policy mixes and achievements towards net zero emissions? The policy mix literature (see Andresen et al., this issue) argues that a broad mix of reinforcing policies are needed to shape the transition towards net zero emissions. We focus on 'push' and 'pull' policies for redirecting and accelerating technological change, green industrial policies, policies for just transition, policy feedback from implementation experiences and economic recovery packages.

Second, goal achievement will depend on the effects of the design of the PA itself on actors' policy mixes and future emissions trajectories. Analyses have so far focused mostly on the significance of the bottom-up design of the PA, contrasting this with the Kyoto Protocol (Dimitrov et al. 2019; Bang et al. 2016). However, we need know more about the actual impact of the PA so far on the targets and policies of the three largest emitters. How has the PA affected the climate policies in China, the EU and the USA?

This article adds new and updated empirical insight in two ways. First, by comparing broad climate policy mixes in the three major emitters. Second, it contributes to knowledge about the effect of the PA on the major emitters' climate ambitions.

We draw on the three previous articles of this special feature (see Bang, Heggelund and Skjærseth) to offer a comparative analysis of climate policy mixes and the effect of the PA in China, the EU and the USA. In the conclusion, we summarize the main findings and briefly discuss the possibilities of reaching the PA's ambitious target.

\section{Comparative policy mixes in China, the EU and the USA}

In this special feature, we have examined the past, present and future climate policies of China, the EU and the USA (see Bang, Heggelund and Skjærseth). More specifically, we have examined policy mixes for various transition functions towards achieving the PA goals. Technological change is seen as crucial in 'green growth' theories for unlocking population/economic growth from resource use and carbon emissions (see Andresen 
et al., this issue). Moreover, the scale of the changes needed will have consequences for wider socioeconomic systems related to employment, economic growth, and distribution of wealth. All these challenges necessitate broad policy mixes or packages. In the following, we draw on the findings in Bang, Heggelund and Skjærseth (this issue) to compare the policy mixes in China, the EU and the USA that are crucial for net zero emissions (summarized in Table 1).

Before we present the results, we should first note that China, the EU and the USA face different energy and socioeconomic challenges and have extremely different political systems with consequences for climate policy (see Bang, Heggelund and Skjærseth and, this issue). The supranational EU decision-making system is characterized by its capacity to act strategically in climate policy with a long-range perspective. In contrast, the many veto points embedded in the federal US system due to the separation of powers between the three branches of government have resulted in policy instability as political polarization has exacerbated since the 1990s. Conversely, the authoritarian Chinese system, based on one political party and five-year plans, is more directed towards incremental change. China's energy mix also differs, although fossil fuels dominate for all three actors: fossilfuel as a share of total energy consumption is $88 \%$ for China, $71 \%$ for the EU and $83 \%$ for the USA (World Bank 2020).

\subsection{Technology push policies}

From a technology perspective, it seems logical to start with public 'push' policies adopted to promote research and innovation in energy technologies. Such policies are crucial to the energy transition needed towards achieving 'well below $2{ }^{\circ} \mathrm{C}$ above pre-industrial levels' (IEA 2020c). The main energy technological options for breaking the emissions trend and meeting the PA targets are to shift the energy mix towards sources emitting less or no $\mathrm{CO}_{2}$; to promote energy saving; and to enable Carbon Capture and Storage (CCS) or equivalent 'removal and storage' options.

Mission Innovation, launched at the 2015 Paris Climate conference by 22 countries (including China and the USA) and the EU, aims at doubling public R\&D low-carbon energy funding by 2021. Since 2014, global public low-carbon energy research and innovation budgets have increased. 'This is also reflected in China, the EU and the USA ${ }^{2}$ : China's budgets grew by $10 \%$ since 2014, while US and EU budgets grew by $7 \%$ (IEA 2020d). However, the EU and the USA are clearly the globally leading regions in publicly funded low-carbon energy research and innovation, each spending about twice as much as China (IEA 2020d).

Concerning organization, EU funding of low-carbon research and innovation increased significantly from 2008 with the EU Strategic Energy Technology Plan (SET-Plan), although it failed to coordinate and concentrate low-carbon technology research and innovation resources at different levels. In contrast, the USA established and has maintained a strong and coordinated federal structure for public support of low-carbon technology innovation since the 1970s. Coordinated efforts across federal government agencies, national laboratories, and universities have resulted in major scientific innovations, addressing large-scale, complex R\&D challenges with an emphasis on translating basic science to

\footnotetext{
1 From about USD 20 billion to 25. https://webstore.iea.org/download/direct/4165.

2 Most energy research/ innovation is funded by the private sector, but comparable data are difficult to find.
} 


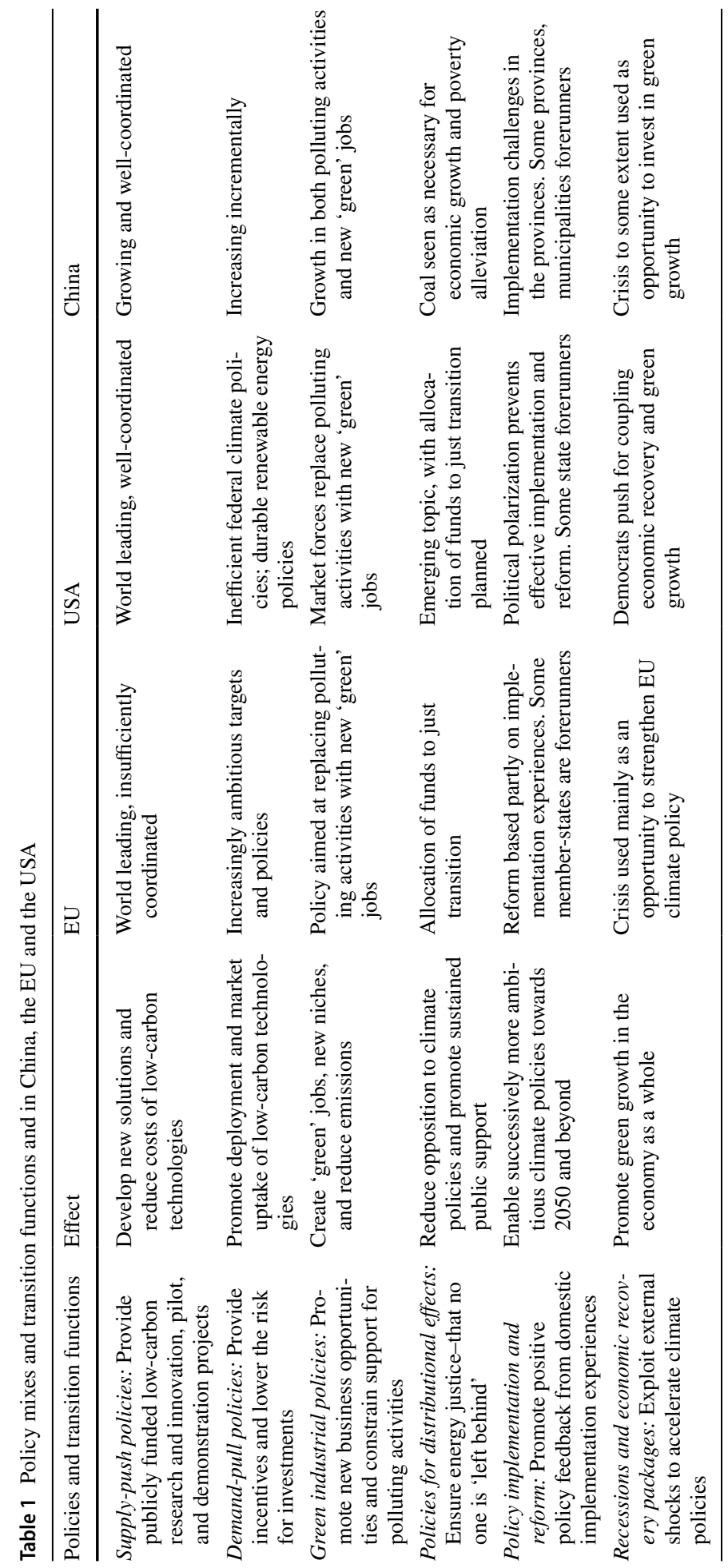


innovation. Bipartisan support in Congress provides stability to these publicly financed push policies. In 2015, China launched the ten-year strategy 'Made in China 2025', aimed at promoting innovation in ten core industries, including the power sector (renewable energy, e.g. solar PV and wind, and new energy vehicles (NEVs) and equipment and batteries. China's growing renewable energy development is increasingly related to national R\&D programmes.

In summary, public low-carbon energy research and innovation funding has increased in all three key actors, but the EU and the USA are the globally leading regions. Coordination of innovation efforts varies from strong in the USA to relatively weak in the EU.

\subsection{Demand-pull policies}

Demand-pull policies such as carbon pricing or support to renewables play a crucial role in the policy mix, together with technology-push instruments for incentivizing the development and deployment of clean energy technology. Such policies will reduce the risks for private investments.

The EU has developed its climate policy from the early 1990s. Since 2007, it has adopted increasingly ambitious climate- and energy targets and binding policies focusing on renewables, energy efficiency and GHG reductions. In December 2020, the European Council agreed on raising the 2030 GHG reduction target from 40 to $55 \%$ (reduction and uptake) compared to 1990 levels. EU climate and energy policies have been linked; and climate-policy legislation has been strengthened with the 2005 EU Emissions Trading System based on an absolute annually decreasing cap and with carbon pricing at the core. The EU's internal energy market has also been reformed to better fit decentralized and variable renewable energy. Since 1990, EU GHG emissions have decreased (also for reasons unrelated to climate policy) by $24 \%$ and the share of renewable energy consumption has more than doubled since 2005. In 2018, renewable energy represented $18.9 \%$ of the energy consumed in the EU, on route towards the 2020 target of $20 \% .^{3}$

US federal climate targets and policies have varied significantly with different presidential administrations, from ambitious attempts at reform under Democratic presidents Clinton and Obama to backlash and status-quo approaches under Republican presidents Bush and Trump. The low durability of federal climate policies has prevented any real federal climate policy effects. Still, in 2018 , GHG emissions had been reduced by $10.2 \%$ from their peak in 2007 (EPA 2020). A market-driven decrease in the use of coal for power generation underpinned the decline in overall US emissions. ${ }^{4}$ Moreover, cuts in GHG emissions were underpinned by growth in renewable energy use. The consumption of renewable energy reached a record $11 \%$ of total U.S. energy consumption in 2019, a doubling since 2005. Renewable energy technologies, particularly solar and wind, were supported over the past two decades by federal legislation and other policy incentives aimed at deployment, such as federal loan guarantees, production tax credits and investment tax credits for commercial and residential projects. Tax credits depend on Congressional approval and were renewed regularly by Congress since first adopted in 1992 (CRS 2020). State-level support varies widely, but most US states have adopted incentive structures in the form of

\footnotetext{
${ }^{3}$ Renewable energy statistics-Statistics Explained (europa.eu).

${ }^{4}$ Coal-fired power plants have been out-competed and replaced by natural gas-fired generation, as gas prices have fallen to lower levels than coal prices apace with the growth of the shale gas fracking industry.
} 
renewable portfolio standards or similar. Moreover, regional and state-level cap-and-trade systems have been implemented in California and in the New England/Mid-Atlantic region.

In China, under the 2007 National Climate Change Programme, energy and climate policies have developed incrementally. In 2018 the authorities reported that carbon intensity had decreased by $45.8 \%$ compared with the 2005 level (MEE 2019). However, in the same year, $\mathrm{CO}_{2}$ emissions in China had increased by 3.7 times compared to 1990, reaching $11.3 \mathrm{Gt} \mathrm{CO}_{2}$ and amounting to $28 \%$ of global emissions (Crippa et al 2019; Le Quéré et al 2018). Improved energy efficiency and a switch to natural gas in cities contributed to carbon-intensity goals. In 2019 , hydro and other renewables sources made up $8 \%$ and $5 \%$, respectively, of total energy consumption, while coal accounted for 58\%..$^{5}$ Notably, the 12th FYP (2011-2015) introduced a carbon mechanism as a way to address carbon emissions (Heggelund et al 2019). The carbon market was politically launched in 2017 with a two-year test and planning period; real trading is scheduled to begin in 2021 (based on relative emission targets for the power sector). In 2020, China unexpectedly decided to peak emissions before 2030, become carbon-neutral by 2060, and enhanced the Nationally Determined Contribution (NDC) goal to reduce carbon intensity by 65\% compared to 2005 (Xinhua 2020b).

Thus, demand-pull policies have become relatively ambitious in the EU, are instable and inefficient at the federal level in the United States and have gradually become more ambitious in China.

\subsection{Green industrial policies}

Policies are also required for 'green' growth and jobs aimed at promoting new 'green' business opportunities while constraining the support for existing polluting industries. The following section focuses mainly on coal. ${ }^{6}$

In the EU, economic growth has been increasingly linked to sustainability. The European Green Deal is framed as a 'green-growth' strategy explicitly aimed at decoupling economic growth from resource use by 2050. EU 'green' industries and jobs have increased significantly. Already in 2013, 'eco' industry companies had a turnover of more than EUR 700 and were estimated to employ over 4.2 million people. ${ }^{7}$ The 2020 'next-generation' EU recovery plan (below) aims to create at least one million 'green' jobs with the Just Transition Fund to help workers in the coal industry into new roles. ${ }^{8}$ If existing coal-fired power plants continue to operate to the end of their life-span, the EU will fail to meet the PA by $2050 .{ }^{9}$ The carbon price has since 2018 influenced a shift away from coal towards renewables and natural gas. ${ }^{10}$ Eight countries, representing $20 \%$ of the EU's total installed coal capacity, have decided to phase out coal by 2030. In Germany, which accounts for

\footnotetext{
5 See Statista (2020) from 2009-2019 renewable energy consumption grew from 0.52 exajoules in 2009 to 6.63 exajoules input equivalent.

6 Figures for 'green growth' are not directly comparable and are used mainly to illustrate the direction in development.

7 https://ec.europa.eu/environment/efe/news/green-jobs-success-story-europe-2016-11-14_en.

${ }^{8}$ https://www.theguardian.com/environment/2020/may/28/eu-green-recovery-package-sets-a-marker-forthe-world.

9 https://climateanalytics.org/briefings/eu-coal-phase-out/.

$10 \mathrm{https} / / / \mathrm{www}$.petroleum-economist.com/articles/markets/trends/2019/carbon-price-drives-generating -fuel-switch.
} 
about one-third of the EU's total installed coal capacity, a government commission has agreed phase out coal by 2038. ${ }^{11}$ Even in the least climate-enthusiastic coal-dependent Poland, agreement has been reached between the government and trade unions on phasing out coal mining by $2049 .{ }^{12}$ Although there is no guarantee that this development will continue, things seem to be heading in the right direction.

In the United States, comprehensive and durable federal green industrial policy packages for promoting new 'green' business opportunities while constraining the support for existing polluting industries are generally lacking. Federal climate policies introduced by President Obama aimed to reduce emissions from polluting industries, such as regulations targeting coal-fired power plants and methane leaks from shale oil and gas drilling. Obama also intensified public investment strategies for creating new and 'greener' jobs. However, these policies were largely rolled back by the Trump administration and replaced with regulatory action aimed at supporting growth in the fossil-fuel industries. Even so, strong demand-pull policies for renewable energy at the state level have encouraged a flourishing 'green' industry. Reports estimate that about $1.2 \%$ of the US workforce-or about 3.3 million people ${ }^{13}$-are working in clean energy industries, outnumbering fossil fuel workers by three to one. ${ }^{14}$ Moreover, the coal industry is dwindling due to market changes. In 2019 coal mining fell to its lowest level since $1978^{15}$ and the number of coal plant retirements is accelerating. ${ }^{16}$

In China, there is growth in both polluting industries like coal, oil and gas, and in 'green' industries. According to figures from IRENA (2020), China is a clear leader in renewable energy employment worldwide: $38 \%$ of the world's total (ibid., p. 22). Renewable energy jobs amounted to appr 4.4 million (IRENA 2020; see Table 1, estimated direct and indirect RE jobs worldwide 2018-19). The PV workforce amounted to 2.2 million jobs, and wind power employment around 518,000 jobs. In 2016, coal mining accounted for some 5 million jobs, out of a workforce of some 800 million, although the sector still supports tens of millions of jobs (Global Commission and IRENA 2019). These figures show that China's green sector is growing (IEA 2020a).

In conclusion, 'green' jobs related to low-carbon energy development are growing in the USA, China and the EU. Concurrently, the coal sector is declining in the EU and the USA, but increasing in China. Only the EU is developing a policy to phase out coal and replace employment in this sector with new 'green' jobs.

\subsection{Policies for distributional effects}

When energy and climate policies become more ambitious, transition support and compensatory relief to, e.g. coal regions or poor energy consumers will be necessary to ensure that no one is 'left behind'. At least in democratic polities, the transition needed to break the emissions trend will fail unless there is sustained public majority support towards 2050 and

\footnotetext{
$11 \mathrm{https} / / \mathrm{www}$. euractiv.com/section/climate-environment/news/only-eight-eu-countries-plan-to-phase-outcoal-by-2030/.

12 https://www.climatechangenews.com/2020/09/25/poland-agrees-coal-mining-phase-unions-2049/.

13 https://www.lse.ac.uk/granthaminstitute/news/how-many-green-jobs-in-the-us/.

14 https://www.forbes.com/sites/energyinnovation/2019/04/22/renewable-energy-job-boom-creating-econo mic-opportunity-as-coal-industry-slumps/?sh=1d0995a03665.

15 https://www.eia.gov/todayinenergy/detail.php?id=44536.

16 https://www.eia.gov/todayinenergy/detail.php?id=44636\#.
} 
beyond. Actors clearly differ in their ideas as to what is socially 'fair' or 'just'. We focus on how the topic is approached in China, the EU, and the USA.

The EU's climate policy has recently placed distributional issues from climate policies among people and regions on the agenda. Distributional concerns have developed, from fairness among member-states and industry sectors, to regions and citizens-note the Yellow vests movement in France. In 2017, the Juncker Commission established the Coal Regions in Transition Platform to facilitate cooperation between affected regions. Several funds have been available to support projects aligned with a just transition: in 2020, it was decided to allocate $€ 17.5$ billion to a specific Just Transition Fund. The EU has also started to pay serious attention to energy poverty, establishing a monitoring system to learn more about the problem. ${ }^{17}$

In the United States, the ideas of 'environmental justice' and a 'fair transition' have only recently emerged as part of the energy transition debate. After pressure from environmental NGOs and the progressive faction of the Democratic Party, a Green New Deal resolution was debated in the House of Representatives in 2019, formally introducing the topics on the US policy agenda. President Biden has included environmental justice and just transition topics in his plans for reforming US climate policy, elevating these concerns to a central place on the policy agenda as adoption and implementation debates begin in 2021. Biden has promised to channel $40 \%$ of the funding in his $\$ 2$ trillion climate policy reform package to environmental justice purposes. ${ }^{18}$

In China, the idea of a just transition has a different meaning, particularly as compared to the EU, as coal is seen as necessary for economic growth and poverty alleviation. Given the uneven development levels throughout the country, interests and priorities between the provinces vary greatly. Coal-producing provinces depend on coal for their economy and employment; other provinces and cities are slowly replacing coal with green-growth industries. Here, the challenge of just transition is likely to emerge if/when emissions are brought towards net-zero in 2060 (see below).

Policies for dealing with distributional issues by enabling a just transition follow the ambitiousness in climate policy. The EU has started to take this seriously by allocating funds, followed by the USA where just transition is an emerging topic. China will have to follow suit in order to attain its own objectives.

\subsection{Policy implementation and reform}

In a long-term perspective, successive policy mixes will be needed in line with the regular 'stock-taking' and increases in ambitions every five years as per the PA. Positive or negative policy feedback will flow from implementation experiences via learning to reform of policies. Implementation challenges for the actors will vary with differing levels of ambition and stages in the policy cycle from initiation to decision-making, implementation, and reform.

The EU has completed the first full climate-policy cycle from policies and implementation directed towards 2020 to reform towards 2030. Implementation is challenging as policies are adopted in Brussels for implementation in 27 member-states. Based partly on mixed or positive experiences and policy feedback from implementing EU policies

\footnotetext{
17 https://ec.europa.eu/energy/topics/markets-and-consumers/energy-consumer-rights/energy-poverty_en.

18 https://joebiden.com/climate-plan/.
} 
for 2020, the reformed EU targets and policies for 2030 became 're-packed' and generally more ambitious. Most member-states, including Germany and France, have been in the forefront, but some Central and East European states have acted as laggards. The policy mix itself offered room for compromise among the member-states, with compensation and special arrangements for the 'least-climate-ambitious' actors, but also aimed at easing the costs for high-income member-states that had to adopt the most ambitious obligations.

In the United States, inherent instability caused by political polarization prevented effective implementation of climate policies. Proposed climate policy reforms, like the 2009 Waxman-Markey climate bill and Obama's many climate-related executive orders, failed to garner bipartisan support and were blocked or removed once Republicans gained majorities in Congress and occupied the White House. As a result, policy learning and positive feedback largely failed in the climate policy field. In the field of renewable-energy policy, however, there was more bipartisan agreement on policy reforms, enabling policy learning and positive feedback and contributing to technology innovation and deployment, in turn helping to cut carbon emissions.

In China, the local authorities are expected to implement the policies set by the central government, which divides responsibility for meeting national targets among the various provinces. The provinces then distribute decision-making targets among their jurisdictions: prefectures, counties, and cities. Local governments will sometimes try to hinder or slow down the implementation of national policies, as these policies may not be well understood or may conflict with local interests. The more economically advanced areas are inclined to push for stringent environmental regulations and to set ambitious energy and climate goals. For instance, Beijing and Shenzhen have set the goal of achieving peak emissions ahead of the 2030 national goal-by 2020 and 2022, respectively. Together with the FYPs, this will increasingly enable the authorities to draw on experiences with implementation when developing new targets towards net zero emissions.

The climate-policy dynamic varies significantly among the three key actors in focus here. The EU has based its policies for 2030 at least partly on previous implementation experiences and learning, whereas implementation and policy cycles in the USA and China are partly blocked by polarization and the provinces, respectively.

\subsection{Recessions and economic recovery packages}

External shocks, like the economic crisis following the coronavirus pandemic, may affect policy development as disrupters of stability, providing windows of opportunity for rapid policy innovation - or causing lower ambitions.

Thus far, the EU has used the crisis chiefly as an opportunity for strengthening the European Green Deal and climate policies. In July 2020, the EU leaders adopted the recovery package 'Next Generation EU' and the Multiannual Financial Framework for 2021-2027, with a combined weight of over $€ 1.8$ trillion. It was decided to dedicate at least $30 \%$ of this package to climate- and environment-relevant spending, but the effect will depend on implementation in member-state recovery and resilience plans.

In the United States, neither the Trump administration nor Congress linked economic responses to climate policy in the $\$ 2.2$ trillion economic stimulus bill (the Coronavirus Aid, Relief, and Economic Security (CARES) Act) adopted in March 2020. Attempts were made by Democrats to add prolonged tax credits for renewable energy projects in the CARES Act, but the Republican majority in the Senate rejected this. In the second stimulus bill adopted in December 2020, a $\$ 900$ billion policy package, extension of federal tax 
credits for wind and solar power plants, as well as tax credits for carbon capture, biofuels and alternative fuels, fuel cells and energy efficiency were included. ${ }^{19}$ Moreover, the Biden administration has promised a distinct green-growth approach in future coronavirus economic recovery plans and other policy reforms. In January 2021, Biden announced his Build Back Better Recovery Plan that aims to increase investments in infrastructure and manufacturing, innovation, research and development, and clean energy. ${ }^{20}$ The plan includes several references to the economic benefits of strengthening sectors like infrastructure in ways that simultaneously create green jobs, boost the economy and reduce emissions.

In China, no economic goals for the coming year were set at the 2020 National People's Congress, due to Covid-19 economic uncertainties. This was viewed as positive for climate change. The authorities have presented stimulus packages, almost $\$ 430$ billion in stimulus payments to help the economy recover from the coronavirus crisis, including climatefriendly initiatives like approval of two new nuclear plants and tax exemptions extended by two years for electric and other clean-energy vehicles. ${ }^{21}$

Thus, only the EU has utilized the coronavirus pandemic mainly as an opportunity for strengthening climate policy by recovery funds.

\section{Paris Agreement and future policies in China, the EU and the USA}

The PA is essentially a bottom-up agreement with universal participation and voluntary domestic policies. In the following some of the key features are first discussed briefly; the intricacies are left to legal scholars, as the PA has been described as incredibly complex (Bodansky 2015). Second, we examine the PA's effect on the three key actors.

The 2014 bilateral agreement between the USA and China was probably the most important building block for the PA. Still, the PA was also a true compromise, as all parties had to give and take, and none got exactly what they wanted. The EU and small island states were successful in ratcheting up ambitions, and French leadership has also been noted as a reason for reaching agreement in Paris (Bodansky 2015). The USA succeeded in designing the PA in line with major US domestic interest; and, by weakening key provisions, the Agreement could be ratified as an Executive Agreement by President Obama hence circumventing the procedural barriers likely to block approvement of a climate treaty in the US Senate, as was the case with the Kyoto Protocol (Hovi et al. 2010).

One main strength of the PA is universal participation in terms of commitments, indicating for the first time that all states are willing to shoulder responsibility. The real achievement of the PA from an environmental effectiveness perspective is that emerging economies such as China take on commitments. Also, all states must provide specific plans through transparent procedures. However, the 'Rulebook' adopted at the 2018 Conference

\footnotetext{
19 https://www.forbes.com/sites/allanmarks/2020/12/21/clean-energy-investments-get-a-bipartisan-boost -from-congress-in-relief-bill/?sh=1e0fff5436f2.

${ }^{20}$ https://buildbackbetter.gov/speeches/remarks-as-prepared-for-delivery-by-president-elect-joe-biden-onthe-american-rescue-plan-and-build-back-better-recovery-plan-in-wilmington-delaware/.

${ }^{21}$ China is investing 25.1 billion yuan charging facilities in the next four years (battery electric, plug-in hybrid and fuel cell, large data centres, 5G infrastructure). IEA (2020b).
} 
of the Parties (COP) and efforts at specifying these procedures show there are still considerable differences between the demands emplaced on participants from the North and the South. ${ }^{22}$ For example, there are no uniform rules regarding reporting procedures. While developed countries report overall emissions, this is not a requirement for developing states. More lax requirements for the emerging economies creates difficulties in comparing progress and ambitions.

Another novel and much-lauded feature is the dynamic nature of the PA, in contrast to the more static Kyoto Protocol. The fact that the process of stepping-up national commitments is legally binding is held to bolster the significance of this process. Still, the international review system is not characterized by enforcement, but by facilitation-necessary to get global support for the Agreement. The most important oversight mechanism is the Global Stocktake. This is potentially an important mechanism for overseeing progress or lack of such. However, it may be a weakness that the focus is primarily on aggregate emissions, not individual ones making it unfeasible to single out individual parties. ${ }^{23}$ Instead, informal political 'shaming and blaming' by NGOs and others is bound to be important. However, this is not necessarily a very effective mechanism; after all, it failed to restrain the USA and Canada from withdrawing from the Kyoto Protocol.

The PA was clearly a political success: universal agreement was reached, and ambitions are very high. However, the price paid for consensus was a vague agreement, as shown by the fact that all states embraced the Agreement despite their highly varying basic interests (Andresen et al. 2016). Its bottom-up approach has been praised for being more realistic than the top-down approach (Falkner 2016). However, domestic pledges are usually less ambitious than a top-down approach (Oberthur and Kelly, 2008).

With the US exit from the PA under the Trump administration, the most powerful player took a backseat. The 2020 COP was intended to be another 'milestone event', as Parties were expected to report new and more ambitious targets-five years after Paris. However, due to the COVID-19 pandemic the meeting was postponed to 2021 and the announcements of new targets from key actors are now expected in $2021 .^{24}$

Despite these challenges, the PA has affected EU policies and targets. The EU pushed for high ambitions in Paris, and the PA has subsequently provided an enabling context for higher EU ambitions. EU climate/energy targets adopted before Paris were based on the $2.0{ }^{\circ} \mathrm{C}$ goal. The $1.5^{\circ} \mathrm{C}$ aspirational PA goal was more ambitious; this gap provided the PA with the potential to affect EU climate and energy policies. Negotiations on energy policies led to more ambitious targets than previously agreed among the EU leaders and proposed by the European Commission. A driving force here was the European Parliament, which actively invoked the PA to further its interests. Although this is difficult to measure precisely, the PA seems to have contributed to empowering particularly the European Parliament's efforts at raising energy efficiency and renewable energy targets. The Agreement has also affected EU climate and energy policies by legalizing the PA's dynamic five-year cycles, making the EU and the PA highly synchronized.

The European Green Deal aims to mainstreaming climate and sustainability concern into all policy areas and sectors. It has three ambitious goals for 2050:1) no net emissions of greenhouse gases; 2) economic growth decoupled from resource use; 3) no person or

\footnotetext{
22 For detailed legal analysis of these provisions, see the Special Issue of Climate Law, 9, 2019.

${ }^{23}$ However, some legal scholars claim that the Global Stocktake also opens up for individual evaluation of the Parties; see Zahar (2019).

24 The EU announced its new 2030 target in 2020.
} 
place left behind. The main EGD initiatives on climate/energy policies have involved raising the 2030 GHG reduction target from 40 to $55 \%$ (reduction and uptake) within the EU by 2030 compared to 1990 and propose a strengthening of the newly adopted climate/ energy policies for 2030 to achieve the new target. All the member states have in principle agreed on net-zero emissions for 2050 in line with the PA.

The USA was a crucial actor in negotiations on the PA, with President Obama's ambitions of international climate leadership as a major driver. However, the effects of the PA dwindled when President Trump withdrew further participation in the Agreement and embarked on an encompassing effort to roll back domestic climate policies. President Biden is re-engaging the USA in international climate cooperation, promising to raise domestic ambitions and pressing for stronger climate action internationally. This shifting state of US positions, in step with changing political majorities on Capitol Hill, hampers US credibility as a reliable long-term partner in the PA. The Biden administration will work to implement very ambitious domestic climate-policy reforms, aimed at decarbonizing the electricity sector by 2035 and achieving a net-zero-emissions economy by 2050 . Biden plans to invest $\$ 2$ trillion over four years to jump-start a green energy transition. However, these climate reforms will need majority support in Congress-which could prove difficult, given the high degree of polarization characterizing the climate-policy field. Regardless, Biden intends to issue executive orders to retract Trump's rollback efforts targeting climate regulations and employ crisis response packages and other legislation to integrate funding for green technology, infrastructure, CCS and other elements that can reinforce the energy transition. Hence, with the Biden administration, we are likely to see an emerging understanding that climate change cannot be addressed in isolation: it is a challenge that requires an encompassing, government-wide response.

Following the US withdrawal, the official tone in China was to continue to support the PA. As to policy, the 13th FYP links domestic climate efforts with the PA, and the goal of achieving carbon-emissions intensity of 60-65 per cent of 2005 levels-objectives developed in relation to the five-year planning cycle. The biggest change is the announcement of the 2060 carbon neutrality during the 2020 UN General Assembly, and the improved NDC goal. China is working on the details for achieving these goals, for inclusion in the 14th FYP (2021-2025) to be released in March 2021. Notably, the Central Committee of the Communist Party of China adopted an Outline for the 14th FYP and a long-term plan (through 2035) prioritizing climate change, green and low-carbon development, and an action plan for achieving $\mathrm{CO}_{2}$ emissions peak before 2030 (Xinhua 2020a). The emphasis on renewables continues in the coming plan; nevertheless, the pathway to carbon neutrality is challenging. Climate change ranks high on the political agenda, but energy security is also a concern, and coal is still regarded the most reliable source. To achieve the carbonneutrality goal, China must reduce its coal consumption drastically during the 14th and 15 th FYPs. Beijing's carbon-neutrality goal is optimistic but will be hard to achieve.

\section{Conclusions}

This article has examined two crucial conditions for achieving the PA's ambitious targets. The first was the domestic climate policies of the three largest emitters, which account for nearly half of the global emissions. What is the status for climate policy mixes and achievements in China, the EU and the USA towards net zero emissions? Policy mixes include policies to both 'push' and 'pull' low-carbon technologies. Polices will also need 
to stimulate new green economic 'niches' and restrict pollutive activities. Such mixes must also ensure a 'just transition', to stave off opposition and promote sustained public support-at least in democratically governed countries. Domestic implementation must result in positive policy feedback as a foundation for stepping up and reforming climate policies, in line with the PA. Finally, responses to crises and economic recession-as with the COVID-19 pandemic-will need to accelerate climate policies to break the current emissions trend.

In our comparison of climate policies in China, the EU and the USA along the above transition functions, we can draw some tentative conclusions. First, the EU has clearly the most ambitious targets and policy mixes that fulfil most of the transition functions identified above. Still, the heavy job remains-to further strengthen and to implement climate policies in all the 27 member states towards 2030 and beyond. Second, the USA and particularly China have adopted comparatively less ambitious targets and policy mixes. There appears to be a clear relationship between climate ambitions and policy mixes for different transition functions. For example, successively more ambitious climate targets necessitate more research and innovation in low-carbon solutions to lower costs, more focus on distributional challenges and 'green' investment in economic recovery packages.

The other condition was related to the design of the PA itself and we asked how the PA has affected the climate policies in China, the EU and the USA? The effect of the PA so far appears to have been strongest in the EU, followed by China. The most ambitious institutions and actors in the EU have actively invoked the PA to further their interests. The EU has also legalized the PA's dynamic five-year cycles, making the EU and the PA highly synchronized. China has used the PA for stepping up climate policies in the five-years programmes and as a foundation for announcement of the 2060 carbon neutrality goal. The USA left the Agreement in 2020 and experienced severe domestic climate-policy setbacks under the Trump administration, but the election of Biden as president is expected to have profound consequences for international climate cooperation. The USA will again be a party to the PA and is set to join the EU and China in their intentions to upgrade climatemitigation policies for 2030 and beyond.

International climate cooperation has experienced many challenges since the PA was adopted in 2015. New record temperatures have been registered, the impacts of climate change are increasingly felt around the world, and total levels of GHG emissions are still rising. Judging from past and current policies of the major emitters, the credibility of the EU ambitious target is highest-but in terms of significance for achieving the PA target, it is also the least important. Future US climate policy is bound to be highly uncertain, given the strong political polarization, but more stable energy policies give grounds for cautious optimism. Uncertainty is even higher when it comes to China, by far the most important actor in this context. A profound transition is needed if Beijing's very ambitious net-zero 2060 target can be reached.

However, more than $50 \%$ of global emissions occur outside these three countries, and this share will increase considerably due to economic and population growth in Asia and Africa. While the COVID-19 crisis has-at least temporarily-brought cuts in carbon emissions, several hurdles remain before the emissions peak is reached. World GHG emissions are expected to be $8 \%$ lower in 2020, due to the pandemic (Bloomberg 2020; DNVGL 2020). These projections show that the transport sector will gradually be wholly electrified; the use of coal will be fully phased out of electricity production, be replaced by renewable energy sources. Still, both these reports conclude that not even the $2{ }^{\circ} \mathrm{C}$ target will be attained. Moreover, such projections rest on the explicit or implicit assumption that public 
policies for enabling the transition need to be continuously strengthened. Our conclusions from the examination of the biggest emitters can only partly confirm this assumption.

Future research on comparative domestic climate policy mixes could broaden the scope and the relationship between the various policies and functions towards net zero emissions. We might have focused more on how technology-push and demand-pull policies are aligned in different stages of the innovation cycle, from ideas to diffusion. Policies for new 'green' industrial development should be expanded to include specific technology areas such as hydrogen and offshore renewable energy, or specific industry sectors. Beyond the policy mix approach, broader state-society relations warrant closer scrutiny. This includes societal demands for climate policies and institutions linking demand and governmental supply in different political systems. Empirically, more countries should be included, to enable more solid assessment of whether the PA targets can be achieved. China, the EU and the USA account for about half of global GHG emissions: next on the list of top emitters are India, Russia, Japan and Brazil.

Future research could also link domestic climate policy mixes to leadership, which has been identified as crucial condition for making the international climate cooperation work (Young 1991; Skodvin and Andresen 2006). With the PA's bottom-up approach, national policies also appear important for unilateral leadership or leadership by example (Underdal, 1992; Oberthur and Kelly 2008; Tiberghien and Schreurs 2009; Skjærseth 2017; Busby and Urpelainen, 2020). In combination, the policy mixes and transition functions referred to above will shape the actors' roles in the PA and their potential to act as leaders by example. China and the USA will have to follow the EU in one way or another if net zero emissions are to be achieved by 2050 or 60 . If that happens (others follow), the EU may be a leader by example that has inspired followers.

\section{References}

Andresen, S., Skjærseth, J. B., Jevnaker, T., \& Wettestad, J. (2016). The Paris agreement: Consequences for the EU and Carbon Markets? Politics and Governance, 4(3), 188-196.

Bang, G., Hovi, J., \& Skodvin, T. (2016). The Paris Agreement: short-term and long-term effectiveness. Politics and Governance, 4(3), 209-218.

Bloomberg (2020) New energy outlook 2020. Report. https://about.bnef.com/new-energy-outlook/.

Bodansky, D (2015) Reflections on the Paris conference. Retrieved from http://opiniojuris.org/2015/!2/15.

Busby, J., \& Urpelainen, J. (2020). Following the leaders? How to restore progress in global climate governance. Global Environmental Politics., 20(4), 99-121.

Congressional Research Service (CRS) (2020). The renewable electricity production tax credit: In Brief. Report. https://fas.org/sgp/crs/misc/R43453.pdf.

Crippa, M., Oreggioni, G., Guizzardi, D., Muntean, M., Schaaf, E., Lo Vullo, E., et al. (2019). Fossil CO2 and GHG emissions of all world countries: 2019 Report. Luxembourg: Publications Office of the European Union. https://doi.org/10.2760/687800.

Dimitriov, R., Hovi, J., Sprinz, D. F., Sælen, H., \& Underdal, A. (2019). Institutional and environmental efectiveness: Will the Paris agreement work? WIREs Climate Change, 10(4), 1-12. https://doi. org/10.1002/wcc.583.

DNV-GL (2020) Energy Transition Outlook 2020. Report. https://eto.dnvgl.com/2020/index.html.

Energy Information Administration (EIA) (2020a). The United States consumed a record amount of renewable energy in 2019. Today in Energy. https://www.eia.gov/todayinenergy/detail.php?id=45516.

Energy Information Administration (EIA) (2020b). International-China U.S. Energy Information Administration (EIA), 30 September.

Ge, M., Friederich, D (2020) Four charts explain greenhouse gas emissions by countries and sectors. World Resources Institute Blog. https://www.wri.org/blog/2020/02/greenhouse-gas-emissions-by-country-sector.

Faulkner, R. (2016). The Paris agreement and the new logic of international climate politics. International Affairs, 92(5), 1107-1125. 
Global Commission of the Geopoliticsand Irena (2019). A New World. The Geopolitics of the energy transformation www.geopoliticsofrenewables.org

Heggelund, G., Stensdal, I., Duan, MS., and Wettestad, J. (2019). China's Development of ETS as a GHG mitigating policy tool: a case of diffusion or domestic drivers? Review of Policy Research https:// onlinelibrary.wiley.com/doi/abs/https://doi.org/10.1111/ropr.12328.

Hovi, J., Sprinz, D., \& Bang, G. (2010). Why the US did not become a party to the Kyoto Protocol: German, Norwegian and US perspectives. European Journal of International Relations, 18(1), 129-150.

IEA (2020a) Post Covid-19, further reform is necessary to accelerate China's clean energy future https:// www.iea.org/articles/post-covid-19-further-reform-is-necessary-to-accelerate-china-s-clean-energ $\mathrm{y}$-future.

IEA (2020b) Energy efficiency can again play a significant role in China's economic recovery https://www. iea.org/commentaries/energy-efficiency-can-again-play-a-significant-role-in-china-s-economic-recov ery.

IEA (2020c) Energy Technology RD\&D Budgets. Statistics Report, pp. 6-11. https://webstore.iea.org/ download/direct/2996?fileName=Energy_Technology_RDD_2020_Overview.pdf.

IEA (2020d): Energy technology perspectives 2020. Report, pp. 318-320. https://webstore.iea.org/downl $\mathrm{oad} /$ direct/4165.

IRENA (2020) Renewable Energy and Jobs-Annual Review 2020, September https://www.irena.org/publi cations/2020/Sep/Renewable-Energy-and-Jobs-Annual-Review-2020.

Quéré, Le., Andrew, R. M., Friedlingstein, P., Sitch, S., Pongratz, J., Manning, A. C., \& Korsbakken, J. I. (2018). Global carbon budget 2017. Earth System Science Data, 10, 405-448. https://doi.org/10.5194/ essd-10-405-2018.

Lin, J., \& Zahar, A. (2019). Introduction to the special issue on the Paris rulebook. Climate Law, 9(12), 1-2.

Ministry of Ecology and Environment (MEE) (2019). UN Climate Action Summit: China's Position and Action 17 September http://english.mee.gov.cn/News_service/news_release/201909/t20190917_73405 1.shtml.

Oberthur, S., \& Kelly, C. R. (2008). EU leadership in international climate policy: Achievements and challenges. The International Spectator, 43, 35-50.

Statista (2020) Consumption of renewable energy in China from 2009 to 2019, China: renewable energy consumption 2019 I Statista.

Skjærseth, J. B. (2017). The European Commission's shifting climate leadership. Global Environmental Politics, 17(2), 84-104.

Skodvin, T., \& Andresen, S. (2006). Leadership revisited. Global Environmental Politics, 6(3), 13-27.

The World Bank (2020) Fossil fuel energy consumption (\% of total)-United States, China, European Union. World Bank open data: https://data.worldbank.org/indicator/EG.USE.COMM.FO.ZS?locat ions=US-CN-EU.

Tiberghien, Y., \& Schreurs, M. (2009). European Union Leadership in climate change: Mitigation through multilevel reinforcement. In K. Harrison \& L. Mcintosh Sundstrom (Eds.), Global commons, domestic decisions. Cambridge: MIT Press.

Underdal, A. (1992). Leadership in International environmental negotiations: Designing feasible solutions. Oslo, Norway: Cicero.

US Environmental Protection Agency (EPA) (2020). Inventory of U.S. Greenhouse gas emissions and sinks: 1990-2018-Executive Summary, pp. 3-4. https://www.epa.gov/sites/production/files/2020-04/docum ents/us-ghg-inventory-2020-chapter-executive-summary.pdf.

Xinhua (2020a). Proposals for formulating the 14th Five-Year Plan (2021-2025) for National Economic and Social Development and the Long-Range Objectives through the Year 2035" by CPC Central Committee adopted at the fifth plenary session) 3 November, http://www.gov.cn/zhengce/2020-11/03/conte nt_5556991.htm.

Xinhua (2020b). Full Text: Remarks by Chinese President Xi Jinping at Climate Ambition Summit-Xinhua I English.news.cn (xinhuanet.com).

Yixeian, S. (2016). The changing role of China in global environmental governance. Rising Powers Quarterly, 1(1), 43-53.

Young, O. R. (1991). Political leadership and regime formation: On the development of institutions in international society. International Organization, 45(3), 281-308.

Zahar, A. (2019). Collective progress in light of equity under the global stocktake. Climate Law, 9, 101-121.

Publisher's Note Springer Nature remains neutral with regard to jurisdictional claims in published maps and institutional affiliations. 